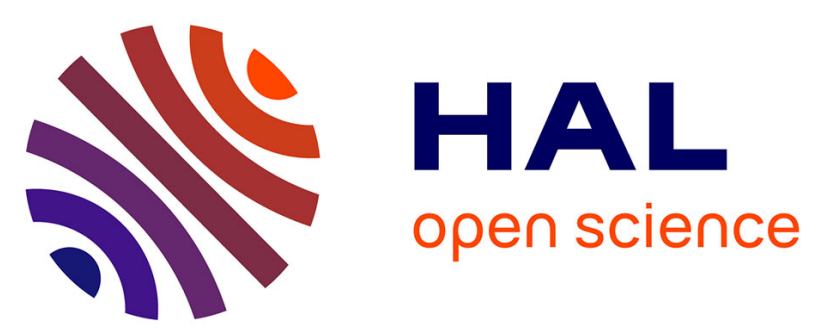

\title{
Decrease of atmospheric deposition of heavy metals in an urban area from 1994 to 2002 (Paris, France)
}

Sam Azimi, Vincent Rocher, Stéphane Garnaud, Gilles Varrault, Daniel R. Thevenot

\section{- To cite this version:}

Sam Azimi, Vincent Rocher, Stéphane Garnaud, Gilles Varrault, Daniel R. Thevenot. Decrease of atmospheric deposition of heavy metals in an urban area from 1994 to 2002 (Paris, France). Chemosphere, 2005, 61 (5), pp.645-651. 10.1016/j.chemosphere.2005.03.022 . hal-01180059

\section{HAL Id: hal-01180059 \\ https://hal.science/hal-01180059}

Submitted on 24 Jul 2015

HAL is a multi-disciplinary open access archive for the deposit and dissemination of scientific research documents, whether they are published or not. The documents may come from teaching and research institutions in France or abroad, or from public or private research centers.
L'archive ouverte pluridisciplinaire HAL, est destinée au dépôt et à la diffusion de documents scientifiques de niveau recherche, publiés ou non, émanant des établissements d'enseignement et de recherche français ou étrangers, des laboratoires publics ou privés. 


\title{
CHEMOSPHERE
}

\section{Decrease of atmospheric deposition of heavy metals in an urban area from 1994 to 2002 (Paris, France)}

\author{
Sam Azimi ${ }^{\mathrm{a}}$, Vincent Rocher ${ }^{\mathrm{a}}$, Stéphane Garnaud ${ }^{\mathrm{b}}$, \\ Gilles Varrault ${ }^{\mathrm{a}, *}$, Daniel R. Thevenot ${ }^{\mathrm{a}}$ \\ a Centre d'Enseignement et de Recherche sur l'Eau la Ville et l'Environnement (Cereve), Université Paris XII-Val de Marne, \\ Faculté de Sciences et Technologie, 61 Avenue du Général de Gaulle, F-94010 Créteil Cedex, France \\ ${ }^{\mathrm{b}}$ Mairie de Paris, Section de l'Assainissement, Cellule Contrôle des Eaux, 17 rue Delesseux, F-75019 Paris, France
}

Received 21 May 2004; received in revised form 4 March 2005; accepted 11 March 2005

Available online 27 April 2005

\begin{abstract}
Total atmospheric deposition, i.e. both wet and dry ones, was sampled during three different sampling periods between 1994 and 2002. The aim of this study is to determine the temporal variation of the atmospheric deposition fluxes of four heavy metals $(\mathrm{Cd}, \mathrm{Cu}, \mathrm{Pb}$ and $\mathrm{Zn})$ in an urban area (Paris region, France). The global pattern shows a decrease of the fluxes for most of elements during this period. Indeed, the atmospheric deposition fluxes measured in 2001-2002 were lower than those measured during the 1994-1997 period by factors reaching 16, 2.5, 4 and 7.5 at Créteil and 7, 1, 6 and 4.5 at Chatou for $\mathrm{Cd}, \mathrm{Cu}, \mathrm{Pb}$ and $\mathrm{Zn}$, respectively. At the Paris site, the decreasing factors were 2.5 and 3 for $\mathrm{Cd}$ and $\mathrm{Pb}$, respectively while $\mathrm{Cu}$ and $\mathrm{Zn}$ fluxes were nearly similar during the whole studied period.

(C) 2005 Elsevier Ltd. All rights reserved.
\end{abstract}

Keywords: Bulk deposition; Fluxes; $\mathrm{Cd} ; \mathrm{Cu} ; \mathrm{Pb} ; \mathrm{Zn}$

\section{Introduction}

Within the last decade, an intensive effort has been made to determine the atmospheric heavy metal composition in both urban and rural areas (Golomb et al., 1997; Migon et al., 1997; Vukmirovic et al., 1997; Injuk et al., 1998; Garnaud et al., 1999). Those previous works have highlighted that the atmosphere is (1) an important pathway for transport of heavy metals and (2) the major external input of bio-available heavy metals to the environment (Jacks, 1990). Such properties have been recog-

\footnotetext{
* Corresponding author. Tel.: +331451716 31; fax: +33145 171627.

E-mail address: varrault@univ-paris12.fr (G. Varrault).
}

nised as potential threats to the environment and human health.

The urban atmosphere is submitted to large inputs of anthropogenic contaminants arising from both stationary (power plants, industries and residential heating) and mobile sources (road traffic) (Bilos et al., 2001). According to their different physical and chemical properties, the size and composition of the source particles, these pollutants are partitioned between particulate, liquid and vapour phases and are subsequently transported to the earth surface through dry and wet deposition (Lawlor and Tipping, 2003). From a biogeochemical perspective, the characterisation of total atmospheric depositions is relevant in order to identify the variability and sources of the atmospheric pollutants. During the past decades, the government efforts to 
control air pollution have achieved some positive effects and, as a result, atmospheric pollutants have been reduced significantly. However, the evidences of the decline in heavy metal concentrations in atmospheric deposition have to be reported.

In this research program, we measured the heavy metal $(\mathrm{Cd}, \mathrm{Cu}, \mathrm{Pb}, \mathrm{Zn}$ ) fluxes in atmospheric deposition during three periods (1994-1997, 1999-2000 and 20012002). The atmospheric deposition was sampled at three stations located in the "Ile-de-France" region: Chatou, Paris and Créteil. Thus, the aim of the present work is to determine the atmospheric deposition variations during an 8-year period in order to assess their temporal variability around an urban area.

\section{Materials and methods}

\subsection{Sites and sampling procedures}

\subsubsection{Sites}

This study was performed in the "Ile-de-France" region which includes Paris city. This area is the most industrialised and densely populated region of France (11 million inhabitants). It includes many waste incinerators, power plants, various industrial plants and, especially, heavy road traffic. Three sampling stations were established in a $20 \mathrm{~km}$ long NW-SE transect through this region (Fig. 1). The first site was situated at Chatou $\left(\mathrm{CHA}, 48^{\circ} 53^{\prime} \mathrm{N}, 02^{\circ} 09^{\prime} \mathrm{E}\right)$ in an urban area without industrial activities, near a lock of the Seine River. The second site, situated in the fourth district of Paris city (PAR, $48^{\circ} 52^{\prime} \mathrm{N}, 02^{\circ} 22^{\prime} \mathrm{E}$ ), was placed on a building flat roof at $18 \mathrm{~m}$ height from the ground level. Two potential sources may mainly affect the atmospheric deposition in this place: heavy road traffic and residential heating. The third site, situated at Créteil (CRE, $48^{\circ} 47^{\prime} \mathrm{N}, 02^{\circ} 28^{\prime} \mathrm{E}$ ), was placed on the flat roof of the Paris XII University building at $20 \mathrm{~m}$ height from ground level. This area is highly industrialised and pre- sents many potential heavy metal emission sources. In addition to a heavy traffic highway (A86, $200 \mathrm{~m}$, West, 60000 vehicles/day), this site is near a power plant $(1900 \mathrm{~m}$, West), two waste incinerators $(5700 \mathrm{~m}$, North-West and $500 \mathrm{~m}$, South) and an international airport (Orly, $8400 \mathrm{~m}$, South-West).

\subsubsection{Sampling procedures}

The atmospheric deposition samples were collected during three different periods. Table 1 presents each sampling date and duration. During the first period, from November 1994 to October 1997, atmospheric deposition was collected successively at Créteil (November 1994 to February 1995), Chatou (February to July 1995) and Paris (May 1995 to October 1997) using the same ARS 1000 collector (MTX-Italia SPA, Modane, Italy). Such device allowed collecting separately dry and wet atmospheric deposition. Both types of samples were collected in polyethylene cylinders $(29 \mathrm{~cm}$ inner diameter) covered with a single lid which automatically swaps from one container to the other, according to a rain detector. The container used for dry deposition was partially filled with ca. $1 \mathrm{~cm}$ high purity water (18.2 M $\Omega$ Milli-Q water, Millipore S.A.) in order to avoid resuspension of collected particles. The sampling duration for individual samples was adapted depending on the occurrence rainfall events, between 5 and 24 days.

During the second sampling period only the Créteil site was equipped (from November 1999 to April 2000), while during the third one, all of the three sites were used (from July 2001 to November 2002). During both sampling periods (periods 2 and 3), the same type of atmospheric collector was used: the atmospheric deposition was collected using funnels connected to polyethylene bottles. These devices were placed inside PVC pipes at a height ranged between 150 and $190 \mathrm{~cm}$ to avoid the collection of re-suspended dust from the roof surface.

The bottles (1 1) and funnels (25 cm inner diameter) used during the period 2, performed at Créteil in

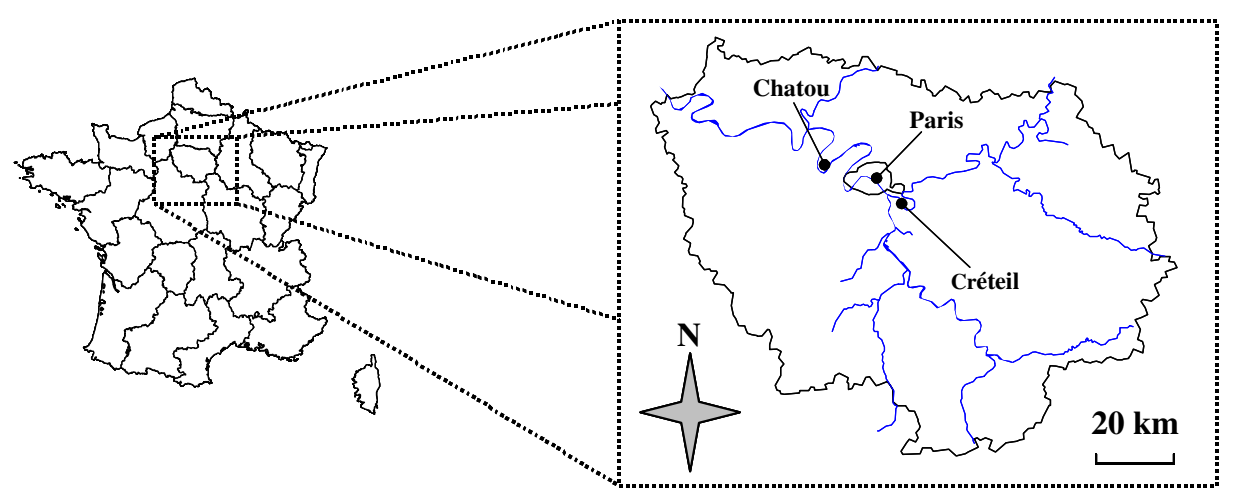

Fig. 1. Sampling locations in the "Ile-de-France" region. 
Table 1

Details of each sampling period

\begin{tabular}{lllcc}
\hline Periods & Sites & Sampling dates & Number of samples & $\begin{array}{l}\text { Mean ( } \pm \text { sd) sampling } \\
\text { duration (days) }\end{array}$ \\
\hline 1 & Créteil & November 1994-February 1995 & 7 & $8 \pm 1$ \\
& Paris & May 1996-October 1997 & 33 & $13 \pm 7$ \\
& Chatou & February 1995-July 1995 & 8 & $10 \pm 3$ \\
2 & Créteil & November 1999-April 2000 & 19 & $7 \pm 3$ \\
3 & Créteil & July 2001-November 2002 & 18 & $27 \pm 5$ \\
& Paris & November 2001-November 2002 & 13 & $29 \pm 9$ \\
& Chatou & July 2001-November 2002 & 18 & $27 \pm 2$ \\
\hline
\end{tabular}

1999-2000, were made of Polyethylene. The collection bottles were filled before each sampling period with $20 \mathrm{ml}$ of a $10 \%$ acidified $\left(\mathrm{HNO}_{3} 65 \%\right.$ Suprapur, Merck) ultra pure water. During the third sampling period, the collection bottles (51) were also made of polyethylene and filled with $50 \mathrm{ml}$ of a $10 \%$ acidified ultra pure water and the funnels $(12 \mathrm{~cm}$ inner diameter) were made of Teflon.

Whatever the sampling period considered the collection materials were rinsed after each sampling period and the rinsing waters were also analysed. For the period 1, both dry and wet ARS 1000 containers were rinsed on site with 11 of $10 \%$ nitric acid to collect metals possibly adsorbed on container walls. During the second and third sampling periods, funnels were rinsed with $100 \mathrm{ml}$ of $10 \%$ nitric acid in order to collect particles deposited or adsorbed on funnel walls.

\subsection{Analysis procedures}

\subsubsection{Sample treatment}

The sample treatment is slightly different for each sampling period (Table 1). The samples obtained during the first period, i.e. from November 1994 to February 1995 (Créteil), February to July 1995 (Chatou) and May 1996 to October 1997 (Paris), were collected using an ARS 1000 collector. Therefore, during each of the sampling durations wet and dry samples were collected separately. The wet deposition samples were acidified at $\mathrm{pH} 1$ for heavy metal determination. A $20 \mathrm{ml} \mathrm{sub-}$ sample of the slurry containing dry deposition was further digested in PTFE beakers with $18 \mathrm{ml} \mathrm{65 \%} \mathrm{nitric}$ acid and $2 \mathrm{ml} \mathrm{70 \%} \mathrm{perchloric} \mathrm{acid} \mathrm{(Merck,} \mathrm{Suprapure)}$ at $110^{\circ} \mathrm{C}$ on a sand bath. After complete evaporation, the remaining solids were dissolved into $30 \mathrm{ml} 1 \mathrm{M}$ nitric acid for metal determination. The atmospheric deposition fluxes were then estimated by summing heavy metals measured in both wet and dry deposition samples.

The samples of the periods 2 and 3, collected without distinction between wet and dry deposition, were completed with concentrated nitric acid after sampling dura- tion to reach a final $\mathrm{pH}$ of 1 and samples were kept in a dark room at $5{ }^{\circ} \mathrm{C}$ during one week in order to dissolve most of the particles. Preliminary experiments have shown that digestion of bulk rain samples or total deposition, with concentrated perchloric and nitric acids, yields similar metal concentrations than $\mathrm{pH} 1$ acidification with nitric acid (Garnaud et al., 1999).

Such sampling procedure ( $\mathrm{pH} 1$ acidification) allows the dissolution of the particles coming from anthropogenic sources (Colin et al., 1990; Desboeufs et al., 2001; Sandroni and Migon, 2002) while particles from crustal origins are not totally digested (Desboeufs et al., 1999). Thus, in this work, heavy metals from natural origins are underestimated. Nevertheless, the four studied elements $(\mathrm{Cd}, \mathrm{Cu}, \mathrm{Pb}, \mathrm{Zn})$ are commonly recognised as mainly emitted from anthropogenic activities (Pacyna, 1998; Pacyna and Pacyna, 2001). After the one week storage, samples were filtered under a class 100 laminar hood with $0.45 \mu \mathrm{m}$ porosity filters (Sartorius, cellulose nitrate). The $60 \mathrm{ml}$ sub-samples obtained were kept at $5{ }^{\circ} \mathrm{C}$ until analysis. The washing procedures of materials are described in detail in Azimi et al. (2003).

\subsubsection{Trace metal analysis}

The heavy metals collected during the first and second campaign were analysed by Atomic Absorption Spectroscopy either in air-acetylene flames $(\mathrm{Zn})$ or in electrothermic graphite furnaces $(\mathrm{Cd}, \mathrm{Cu}, \mathrm{Pb})$ depending on the metal concentration with addition of a matrix modifier in the case of $\mathrm{Cd}$. During the third campaign, an ICP-AES (Perkin Elmer Optima 3000) with an ultrasonic nebuliser and an axial slit was used. The two devices, combined together, enhance the sensitivity and the detection limits for trace element analysis. Whatever the device used (AAS or ICP-AES), a quality control was performed using some test samples which were treated like the atmospheric deposition. These samples were (1) acidified water blanks to check the contamination during sample treatment in laboratory and (2) acidified water blanks to check the contamination during field collection. The method accuracy was assessed by 
analysis of two certified samples in heavy metals presenting similar concentrations as atmospheric deposition (Azimi et al., 2003): NIST 1643d and SPS-SW1 batch 105. The results showed that, whatever the element considered, the analysis bias was less than $15 \%$.

\section{Results and discussion}

\subsection{Meteorological conditions}

In order to compare the atmospheric deposition fluxes within a 8-year period, the study of meteorological conditions appears of prime importance. Thus, the wind direction and the rainfall amount of the Paris location during the first and last sampling periods, i.e. from May 1996 to October 1997 and from November 2001 to October 2002, respectively, were compared. These data were measured by Météo-France at the Paris-Montsouris site, placed in the 14 th district of the city. Table 2 presents the wind direction, expressed as relative day frequency $(\%)$, from each sector (North-East: N-E, South-East: S-E, South-West: S-W, North-West: N-W) during the whole duration of each sampling period as well as the rainfall amount $\left(\mathrm{mm} \mathrm{y}^{-1}\right)$. Whatever sampling period considered, the wind blew the same way at the Paris site. The relative daily frequencies of wind, blowing from N-E and S-W were $23 \%$ and $35 \%$ of the time considering the first sampling period (1996-1997) and $25 \%$ and $35 \%$ for the second one, respectively. The global pattern of the wind direction appears as similar during both campaigns. Since Garban et al. (2002) showed that wind conditions were quiet similar in the whole area, we assumed that the wind conditions were similar for all the studied sites. Moreover, the rainfall amount during each sampling period was equivalent. The 2001-2002 sampling period rainfall amount was only $8 \%$ higher than the 1996-1997 one. Considering the second sampling period (Créteil in 2000) the rainfall amount was estimated at $527 \mathrm{~mm} \mathrm{y}^{-1}$ which is in the same order of magnitude than the rainfall amount of the two other periods. Therefore, the meteorological conditions during these different sampling periods ap- peared to be similar and could be then discarded as a cause of the variations of the heavy metal deposition fluxes.

\subsection{Annual variation of atmospheric deposition}

As described in the sampling procedure section, the collection material was always rinsed after each sampling period. To better estimate the heavy metal deposition fluxes, we have also considered heavy metal quantities contained in these rinsing waters. Indeed, it appears that a significant amount of heavy metals collected by such device (bottles and funnels) is released from the funnel walls during the rinsing step (Azimi et al., 2003). In order to investigate the seasonal patterns of atmospheric deposition of heavy metals over the "Ile-de-France" area, Fig. 2 presents the seasonal variation of $\mathrm{Cd}, \mathrm{Cu}, \mathrm{Pb}$ and $\mathrm{Zn}$ in the atmospheric deposition for each sampling period at Chatou and Paris and Fig. 3 presents those at the Créteil site. To evaluate the variation of the deposition fluxes, we have considered the 10th and the 90th (d10 and d90, respectively) percentiles; the factor of variation is evaluated as the $\mathrm{d} 90 / \mathrm{d} 10$ ratio (Rocher et al., 2003).

Considering the first sampling period at Chatou and Paris sites (Fig. 2) (from February to July 1995 and from May 1996 to October 1997, respectively) the factor of variation of the deposition fluxes was ranged from 2 to 4 and 3 to 6 whatever the considered element. Looking at the July 2001-November 2002 sampling period, the same factor of variation of deposition fluxes was observed since the $\mathrm{d} 90 / \mathrm{d} 10$ ratio was ranged from 2 to 6 for both sites. Thus, the heavy metal flux variation was quite similar between both periods (1995 and 2002) at Chatou and Paris for $\mathrm{Cd}, \mathrm{Cu}, \mathrm{Pb}$ and $\mathrm{Zn}$.

The main difference was observed at the Créteil site (Fig. 3). During the first sampling period (from November 1994 to February 1995), the factor of variation was 9, 4, 4 and 5 for $\mathrm{Cd}, \mathrm{Cu}, \mathrm{Pb}$ and $\mathrm{Zn}$, respectively and, during the second period (from November 1999 to April 2000), the variation factors were 16,2 and 2 for $\mathrm{Cd}, \mathrm{Cu}$ and $\mathrm{Pb}$, respectively. During this sampling campaign, the $\mathrm{Zn}$ fluxes were not measured. For the last sampling

Table 2

Meteorological data during the two longest sampling periods in the Paris city, near the Paris sampling site

\begin{tabular}{llcc}
\hline & & Sampling periods & \\
\cline { 3 - 4 } & & $1996-1997$ & $2001-2002$ \\
\hline Wind direction (relative day frequency) & N-E & 23 & 25 \\
& S-E & 22 & 13 \\
Sampling duration (days) & S-W & 35 & 35 \\
Rainfall amount (mm y ${ }^{-1}$ ) & & 20 & 334 \\
\hline
\end{tabular}



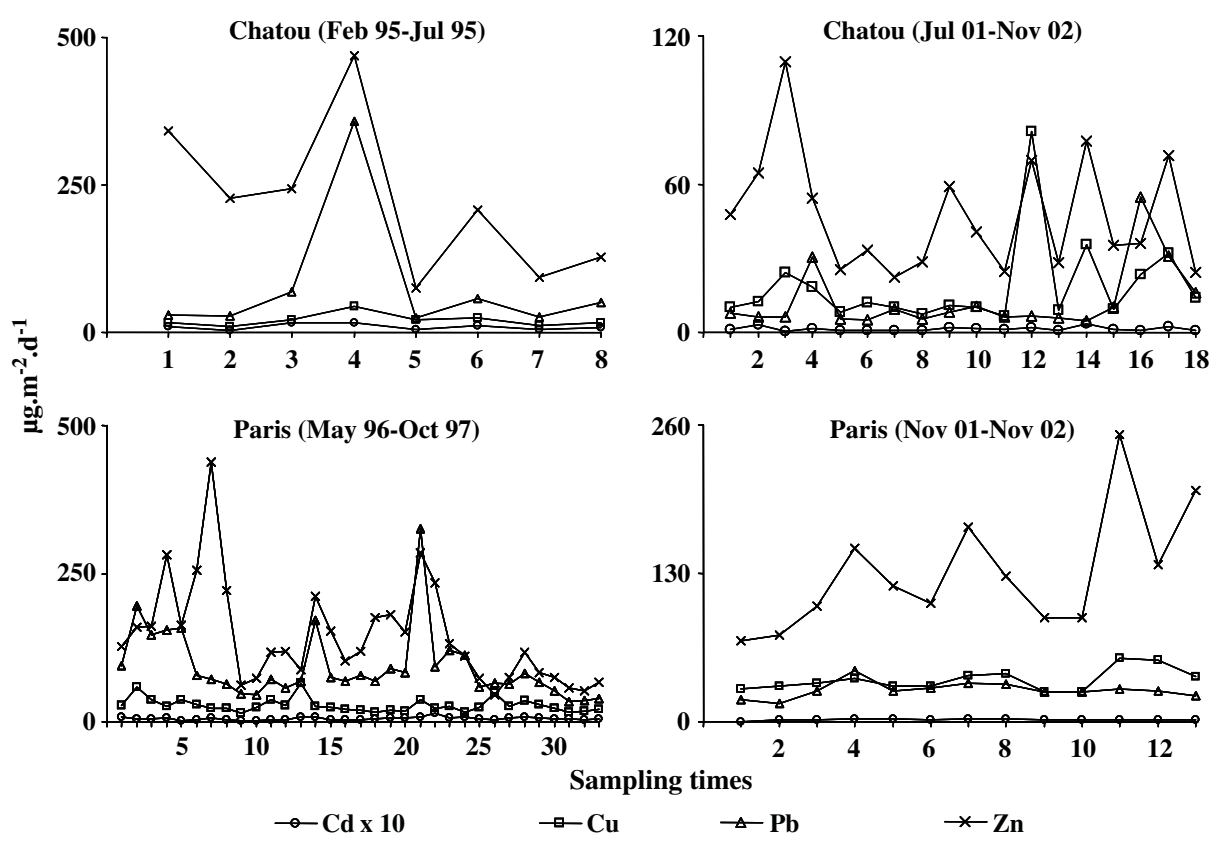

Fig. 2. Temporal variation of atmospheric deposition at Chatou and Paris during the two different periods (1995-1996 and 20012002).

period (from July 2001 to November 2002), the factor of variation of deposition fluxes was ranged from 2 to 3 for all elements. These results, showing the decrease of the flux variation of the heavy metals, mainly in the case of the $\mathrm{Cd}$, at the Créteil site, which is an industrialised area, may reflect the recent steadily of emission rates of the main industrialised sources. Such patterns can result from the better treatment of the emission flue gas from such sources. While at the two other sites (Paris and Chatou), the main anthropogenic sources are not from industrial origins but urban heating and road traffic.

\subsection{Long time variation of atmospheric deposition}

However, the improvement carried out to the flue gas treatment, and on the whole, to all type of anthropogenic emissions is more obvious when studying the annual deposition amount for each sampling period. Thus, to perform such comparison, between each studied period (Table 1), we have aggregated the one year flux amounts of each of them. In most of the cases, i.e. for the Paris site from 1996 to 1997 and for Chatou, Paris and Créteil from 2001 to 2002, the studies have been carried out for more than a year. Therefore, the annual variations described below have been taken into account in the annual deposition amounts. For the studied periods from November 1994 to February 1995 and from November 1999 to April 2000 at the Créteil site and from February to July 1995 at the Chatou site, the annual deposition amounts have been extrapolated. Indeed, these three studies lasted less than a year. However, two main points reflect the validity of the estimation of annual atmospheric deposition by a calculation method. Firstly, on sites where the study was performed more than a year, the atmospheric deposition variations were found to be weak (between 2 and 6 for $\mathrm{Cu}, \mathrm{Pb}$ and $\mathrm{Zn})$. Secondly, many other works on atmospheric deposition variation showed that the deposition fluxes of heavy metals are not dependent on seasons (Golomb et al., 1997; Bilos et al., 2001; Azimi et al., 2004, 2005) since their main sources are quite constant throughout the year. Thus, for each site and period, we have calculated the annual flux deposition of atmospheric fallout of $\mathrm{Cd}, \mathrm{Cu}, \mathrm{Pb}$ and $\mathrm{Zn}$ to study their long time variations, i.e. from 1994 to 2002.

Fig. 4 shows the 8-year trend of the $\mathrm{Cd}, \mathrm{Cu}, \mathrm{Pb}$ and $\mathrm{Zn}$ deposition fluxes $\left(\mathrm{mg} \mathrm{m}^{-2} \mathrm{y}^{-1}\right)$ at Créteil, Chatou and Paris sites. The 1994-1997 and 2000 annual fluxes were assessed by the sum of dry and wet deposition fluxes while 2001-2002 period values were determined with total atmospheric deposition collection. Indeed, Azimi et al. (2003) showed that in urban areas, there was no significant difference in the atmospheric deposition flux estimation using both collection procedures. The global pattern showed a decrease in atmospheric deposition load between 1994 and 2002. The annual atmospheric deposition fluxes determined at Chatou were $0.34,8,31$ and $76 \mathrm{mg} \mathrm{m}^{-2} \mathrm{y}^{-1}$ for $\mathrm{Cd}, \mathrm{Cu}, \mathrm{Pb}$ and $\mathrm{Zn}$, respectively, during the 1995 sampling period. 

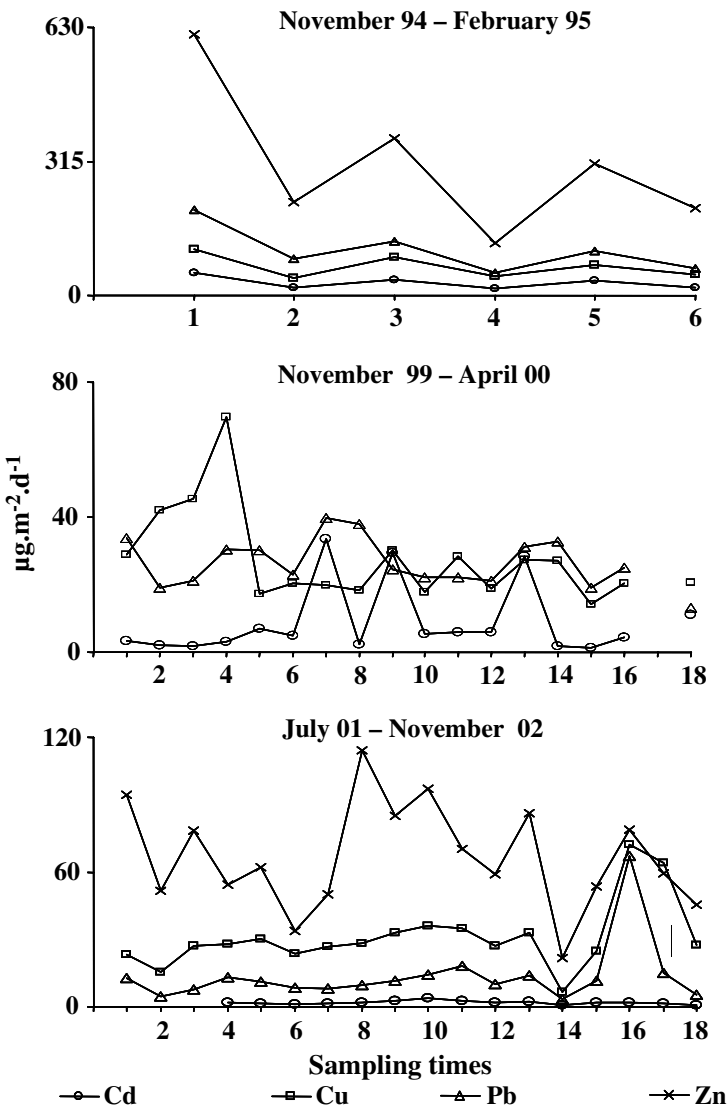

Fig. 3. Temporal variation of atmospheric deposition at the Créteil sampling site during the three sampling periods (1994 1995, 1999-2000, 2001-2002).

The calculated decreasing factor between this period and the 2001-2002 one was 7, 1, 6 and 4.5, respectively. The decreasing factors calculated for the Paris site were 2.5, 1,3 and 1 for $\mathrm{Cd}, \mathrm{Cu}, \mathrm{Pb}$ and $\mathrm{Zn}$, respectively, between 1996-1997 and 2001-2002. Thus, a significant decrease appeared (statistical one tailed $t$-test, 99\% confidence level) for $\mathrm{Cd}, \mathrm{Pb}$ and $\mathrm{Zn}$ at Chatou while at Paris the significant decrease appeared only for $\mathrm{Cd}$ and $\mathrm{Pb}$. Such difference in $\mathrm{Cu}$ and $\mathrm{Zn}$ flux behaviour at Chatou and Paris sites reflects the difference in their source apportionment. Indeed, $\mathrm{Cu}$ and $\mathrm{Pb}$ are commonly considered as mainly emitted by the road traffic (Öblad and Selin, 1985; Weckwerth, 2001; Sternbeck et al., 2002), an important source near this site. The use of unleaded gasoline from the year 2000 induced a decrease of lead emissions from this source. As a result, it is only the latter element which shows a decrease in the atmospheric deposition while the copper flux stays quite similar in atmospheric deposition during the 8-year period considered. Considering the case of $\mathrm{Zn}$ at the Paris site, it appears that this site acts as a source for this element.
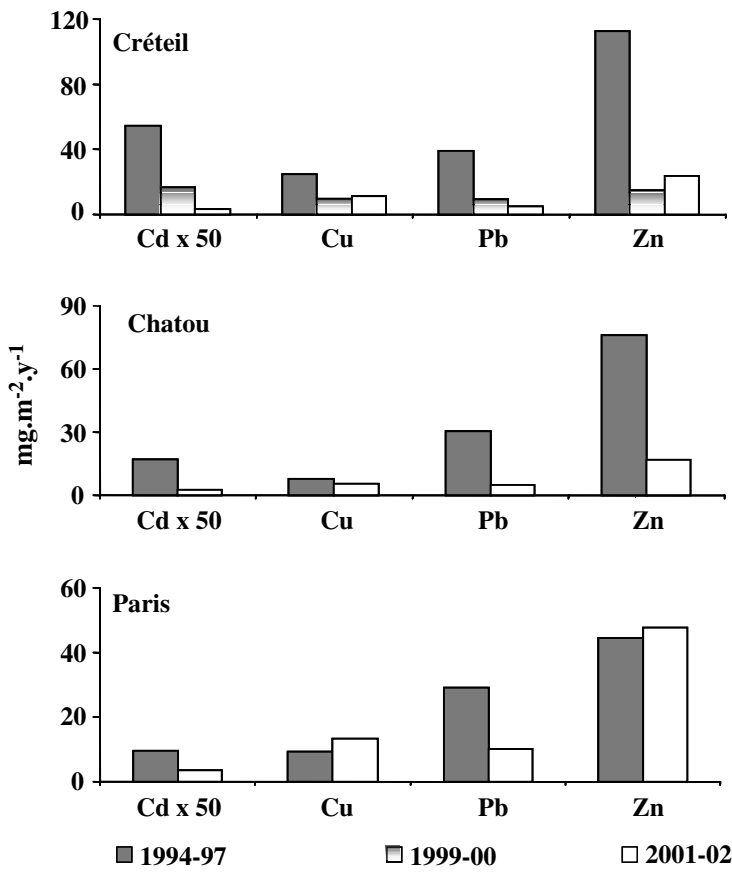

Fig. 4. Annual atmospheric deposition fluxes of $\mathrm{Cd}, \mathrm{Cu}, \mathrm{Pb}$ and $\mathrm{Zn}$ obtained during each sampling period (from 1994 to 1997, 1999-2000 and 2001-2002) at Créteil, Chatou and Paris.

Indeed, the roof covering material of this area is mainly composed by zinc sheets and a combination of zinc sheets and slate tiles (Gromaire-Mertz et al., 1999). Rocher et al. (2004) showed that such type of roof covering material induced high amounts of zinc in roof runoff waters during rain events (80 times higher than atmospheric deposition). Such enrichment may highly influence the atmospheric deposition at this location, inducing a steady atmospheric deposition amount of zinc during the 8-year period studied.

At the Créteil site, the 1994-1995 deposition fluxes were equal to $1.1,25,39$ and $113 \mathrm{mg} \mathrm{m}^{-2} \mathrm{y}^{-1}$ for $\mathrm{Cd}$, $\mathrm{Cu}, \mathrm{Pb}$ and $\mathrm{Zn}$, respectively. The 1999-2000 deposition fluxes, equal to $0.34,10,9.5$, and $15 \mathrm{mg} \mathrm{m}^{-2} \mathrm{y}^{-1}$ show a decrease of atmospheric deposition of these elements (by a factor of 3, 2.5, 4 and 7.5, respectively) between 1994 and 2000. Between periods 1999-2000 and 20012002, quite similar deposition amounts were observed for the $\mathrm{Cu}, \mathrm{Pb}$ and $\mathrm{Zn}$ while $\mathrm{Cd}$ fluxes decreased by a factor of 5. Thus, Cd flux was decreased by a factor of 16 between 1994 and 2002 at the Créteil site. This region is under the influence of many stationary sources. Therefore, a better treatment of the flue gas emissions by various stationary sources (power plants, waste incinerators) is more likely to be responsible of such large improvement in air quality of this industrialised area. 


\section{Conclusion}

Atmospheric bulk deposition was sampled at three sites in the Paris area during three sampling periods in 1994-1997, 1999-2000 and 2001-2002. The global pattern shows a decrease of the fluxes for most of elements during this period. Indeed, except the $\mathrm{Cu}$ and $\mathrm{Zn}$ cases at the Paris site and the $\mathrm{Cu}$ at Chatou, the atmospheric deposition fluxes measured in 2001-2002 were lower than those measured during the 1994-1997 period by factors reaching 16, 2.5, 4 and 7.5 at Créteil for $\mathrm{Cd}$, $\mathrm{Cu}, \mathrm{Pb}$ and $\mathrm{Zn}$, respectively and 7, 6 and 4.5 at Chatou for $\mathrm{Cd}, \mathrm{Pb}$ and $\mathrm{Zn}$, respectively. At the Paris site, the decreasing factors were 2.5 and 3 for $\mathrm{Cd}$ and $\mathrm{Pb}$, respectively while $\mathrm{Cu}$ and $\mathrm{Zn}$ fluxes were slightly similar during the whole studied period. Such results may be linked to the use of unleaded gasoline, inducing the decrease of $\mathrm{Pb}$ and a better flue gas treatment of stationary sources. Nevertheless, a local influence of the roofs seems to induce a quite similar deposition amount of $\mathrm{Zn}$ at the Paris site.

\section{Acknowledgments}

Authors are grateful to V. Roy (Laboratoire de Biologie des Sols et des Eaux) and E. Bon-Nguyen (Laboratoire Interuniversitaire des Systèmes Atmosphériques) for their scientific support. This work was financially supported by the PIREN-Seine research program (CNRS GDR 1067). The cooperation of P. Ansart (Cemagref) and the headmistress of the Ste Geneviève School is fully acknowledged.

\section{References}

Azimi, S., Ludwig, A., Thévenot, D.R., Colin, J.-L., 2003. Trace metal determination in total atmospheric deposition in rural and urban areas. Sci. Total Environ. 308, 247-254.

Azimi, S., Cambier, P., Lécuyer, I., Thévenot, D.R., 2004. Heavy metal determination in atmospheric deposition and other fluxes in northern France agrosystems. Water Air Soil Pollut. 157, 295-313.

Azimi, S., Rocher, V., Muller, M., Moilleron, R., Thévenot, D.R., 2005. Sources, distribution and variability of hydrocarbons and metals in atmospheric deposition in an urban area (Paris, France). Sci. Total Environ. 337, 223-239.

Bilos, C., Colombo, J.C., Skorupka, C.N., Rodriguez Presa, M.J., 2001. Sources, distribution and variability of airborne trace metals in La Plata City area, Argentina. Environ. Pollut. 111, 149-158.

Colin, J.L., Jaffrezo, J.L., Gros, J.M., 1990. Solubility of major species in precipitation: factors of variation. Atmos. Environ. $25 \mathrm{~A}, 537-544$.

Desboeufs, K.V., Losno, R., Vimeux, F., Cholbi, S., 1999. pH Dependent dissolution of wind transported Saharan dust. J. Geophys. Res. 104, 21287-21299.
Desboeufs, K., Losno, R., Colin, J.L., 2001. Factors influencing aerosol solubility during cloud processes. Atmos. Environ. 35, 3529-3537.

Garban, B., Blanchoud, H., Motelay-Massei, A., Chevreuil, M., Ollivon, D., 2002. Atmospheric bulk deposition of PAHs onto France: trends from urban to remote sites. Atmos. Environ. 36, 5395-5403.

Garnaud, S., Mouchel, J.-M., Chebbo, G., Thévenot, D.R., 1999. Heavy metal concentrations in dry and wet atmospheric deposits in Paris district: comparison with urban runoff. Sci. Total Environ. 235, 235-245.

Golomb, D., Ryan, D., Eby, N., Underhill, J., Zemba, S., 1997. Atmospheric deposition of toxic onto Massachusetts Bay-I. Metals. Atmos. Environ. 31, 1349-1359.

Gromaire-Mertz, M.C., Garnaud, S., Gonzalez, A., Chebbo, G., 1999. Characterisation of urban runoff pollution in Paris. Water Sci. Technol. 39, 1-8.

Injuk, J., Van Grieken, R., De Leeuw, G., 1998. Deposition of atmospheric trace element into the North Sea: Coastal, ship, platform measurements and model predictions. Atmos. Environ. 32, 3011-3025.

Jacks, G., 1990. Mineral weathering studies in Scandinavia. In: Mason (Ed.), The Surface Waters Acidification Programme. Cambridge University Press, Cambridge, pp. 215-222.

Lawlor, A.J., Tipping, E., 2003. Metals in bulk deposition and surface water at two upland locations in northern England. Environ. Pollut. 121, 153-167.

Migon, C., Journel, B., Nicolas, E., 1997. Measurement of trace metal wet, dry and total atmospheric fluxes over the Ligurian Sea. Atmos. Environ. 31, 889-896.

Öblad, M., Selin, E., 1985. Measurement of $\mathrm{Br} / \mathrm{Pb}$ ratios in airborne particles from car exhaust. Phys. Scripta 32, 462468.

Pacyna, J.M., 1998. Source inventories for atmospheric trace metals. In: Harrison, R. (Ed.), Atmospheric Particles. Wiley, Europe, pp. 385-423.

Pacyna, J.M., Pacyna, E.G., 2001. An assessment of global and regional emissions of trace metals to the atmosphere from anthropogenic sources worldwide. Environ. Rev. 9, 269298.

Rocher, V., Azimi, S., Garnaud, S., Moilleron, R., Chebbo, G., 2003. Pollution métallique associée au dépôt du réseau d'assainissement de la ville de Paris. TSM 10, 75-86.

Rocher, V., Azimi, S., Gasperi, J., Beuvin, L., Muller, M., Moilleron, R., Chebbo, G., 2004. Hydrocarbons and metals in atmospheric deposition and roof runoff in central Paris. Water Air Soil Pollut. 159, 67-86.

Sandroni, V., Migon, C., 2002. Atmospheric deposition of metallic pollutants over the Ligurian Sea: labile and residual inputs. Chemosphere 47, 753-764.

Sternbeck, J., Sjodin, A., Andreasson, K., 2002. Metal emissions from road traffic and the influence of resuspensionresults from two tunnel studies. Atmos. Environ. 36, 4735-4744.

Vukmirovic, Z., Marendic Miljkovic, J., Rajsic, S., Tasic, M., Novakovic, L.A., 1997. Resuspension of trace metals in Belgrade under conditions of drastically reduced emission levels. Water Air Soil Pollut. 93, 137-156.

Weckwerth, G., 2001. Verification of traffic emitted aerosol components in the ambiant air of Cologne (Germany). Atmos. Environ. 35, 5525-5536. 